\section{Primary biliary cirrhosis in mother and daughter}

The cause of primary biliary cirrhosis remains obscure, and the interrelation between genetic and environmental factors is unknown. Reports of familial primary biliary cirrhosis therefore arouse interest, but until 1976 these were few and confined to paired siblings. Recently primary biliary cirrhosis has been described in a mother and daughter. ${ }^{1}$ We describe here another two cases of mother and daughter who both developed the disease, but in these patients environmental factors also seemed to play an important part in the genesis of the condition.

\section{Case 1}

This 43-year-old housewife (the propositus) was referred in 1976 for investigation of hepatomegaly and melaena. She had had a transient episode of jaundice in 1955 after an appendicectomy and had been in Singapore from 1964 to 1966. She had experienced abdominal discomfort and flatulence thereafter and had noticed intermittent pruritus since 1974.

On admission she was slightly pigmented, with no other stigmata of chronic liver disease except leuconychia. The liver was firm, smooth, and palpable $7 \mathrm{~cm}$ below the costal margin, and the spleen was palpable at $3 \mathrm{~cm}$. There was no ascites. Liver function tests showed bilirubin $27 \mu \mathrm{mol} / 1$ $(1.6 \mathrm{mg} / 100 \mathrm{ml})$, alkaline phosphatase $600 \mathrm{IU} / \mathrm{l}$, aspartate transaminase $99 \mathrm{IU} / \mathrm{l}$, prothrombin time prolonged at 3 seconds, albumin $40 \mathrm{~g} / \mathrm{l}$, total globulin $33 \mathrm{~g} / \mathrm{l}$, and cholesterol $5.5 \mathrm{mmol} / 1(212 \mathrm{mg} / 100 \mathrm{ml})$. Antinuclear antibodies, smooth-muscle antibodies, rheumatoid factor, cold agglutinins, and hepatitis B surface antigen were not present. Antimitochondrial antibodies were positive to a titre of $1 / 640$. Serum $\operatorname{IgG}, \operatorname{IgA}$, and $\operatorname{IgM}$ concentrations were $16 \cdot 2,3 \cdot 2$, and $9 \cdot 5 \mathrm{~g} / 1$, respectively. A barium swallow examination showed gross varices. Liver biopsy showed a typical pattern of biliary-type cirrhosis (proliferative phase) with expanded portal tracts, proliferated ductules, and occasional lymphocytes. Interlobular ducts were absent.

\section{Case 2}

In 1971 the 69-year-old mother of the propositus was referred to Essex County Hospital, Colchester, after having had a melaena. She complained of severe long-standing Raynaud's phenomenon. She had been separated from her daughter for one year only, in 1964, but she then rejoined her in Singapore in 1965.

On admission she was strongly pigmented with spider naevi and gross leuconychia. Liver function tests showed bilirubin $20.5 \mu \mathrm{mol} / 1(1.2 \mathrm{mg} / 100$ $\mathrm{ml}$ ), alkaline phosphatase $440 \mathrm{IU} / 1$, aspartate transaminase $61 \mathrm{IU} / 1$, albumin $37 \mathrm{~g} / \mathrm{l}$, and total globulin $26 \mathrm{~g} / \mathrm{l}$. She was positive for cold agglutinins. Autoantibodies and serum cholesterol were not measured. Barium swallow examination showed varices. Over the next five months she complained of pruritus and was readmitted with further melaena and a haematemesis. At laparotomy in November 1971, ascites and a "cirrhotic" liver were found. The portal pressure was $20 \mathrm{~cm} \mathrm{H}, \mathrm{O}$. Despite a portacaval shunt, the patient became progressively jaundiced and died within three weeks. The findings on liver biopsy (from laparotomy) were consistent with primary biliary cirrhosis, with enlarged portal areas, extensive proliferation of ductules, fibrous septa, and few mixed inflammatory cells. Interlobular ducts were absent. A lymph node from the hepatic hilum at laparotomy showed follicular hyperplasia, sinus histiocytosis, and sarcoid-like granulomata.

\section{Comment}

Familial primary biliary cirrhosis is rare, although autoantibodies and abnormalities in immunoglobulins may be found in $7-16 \%$ of asymptomatic relations." ${ }^{3}$ Evidence in support of a genetic predisposition to the development of the condition includes its occurrence in siblings, including twins. ${ }^{4}$. Recently Tong et al reported a mother and daughter with primary biliary cirrhosis $^{1}$ in association with HLA-A1 and B8 histocompatibility antigens, but the relative importance of genetic and environmental influences is always difficult to assess. On tissue typing, none of the members of the family of our patients were found to carry HLA-A1 and B8 (see figure). Only the

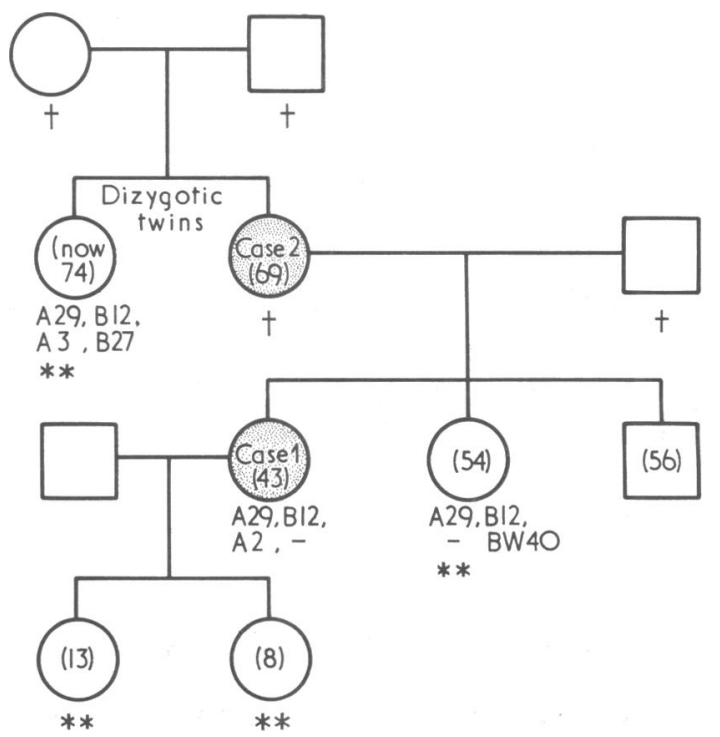

Details of the family studied. Hatched circles indicate patients with primary biliary cirrhosis. Ages are given in parentheses. ${ }^{* *}$ Negative for autoantibodies and immunoglobulins.

mother and daughter had continued to live together, and this, together with the fact that they presented with primary biliary cirrhosis within five years of each other, suggests that an environmental factor, probably interacting with genetic components, may have been of prime importance in initiating bile duct destruction. The response to this environmental influence seems likely to have occurred in the recent past rather than in childhood.

We thank Dr R Vasey, Sunderland Royal Infirmary, and Miss L Kennedy, Guy's Hospital tissue typing laboratory, for their help and Professor J R Batchelor for his constructive criticism.

1 Tong, M J, et al, Gastroenterology, 1976, 71, 305.

2 Galbraith, R M, et al, British Medical fournal, 1974, 3, 604.

${ }^{3}$ Feizi, T, et al, Clinical and Experimental Immunology, 1972, 10, 609.

${ }^{4}$ Chohan, M R, Gut, 1973, 14, 213.

${ }^{5}$ Maddrey, W C, et al, Annals of Internal Medicine, 1964, 61, 667.

(Accepted 22 fune 1977)

Liver Unit, King's College Hospital and Medical School, London SE5 ELIZABETH FAGAN, BSC, $M B$, house physician ROGER WILLIAMS, MD, FRCP, director of unit and consultant physician

Clacton and District Hospitals, Clacton-on-sea, Essex

SIMON COX, MB, BS, general practitioner 